International Journal of Current Advanced Research

ISSN: O: 2319-6475, ISSN: P: 2319-6505, Impact Factor: SJIF: 5.995

Available Online at www.journalijcar.org

Volume 6; Issue 8; August 2017; Page No. 5397-5399

DOI: http://dx.doi.org/10.24327/ijcar.2017.5399.0716

Research Article

\title{
NON FERMENTERS ARE EMERGING FROM PYOGENIC LESIONS: A CASE SERIES FROM BURDWAN MEDICAL COLLEGE
}

\section{Subhra Saha, Purbasha Ghosh, G.D Mitra and Santanu Pramanik}

Department of Microbiology, Burdwan Medical College

\section{A R T I C L E I N F O}

\section{Article History:}

Received $17^{\text {th }}$ May, 2017

Received in revised form $22^{\text {nd }}$

June, 2017 Accepted $6^{\text {th }}$ July, 2017

Published online $28^{\text {th }}$ August, 2017

Key words:

Pyogenic lesions, Non-fermenters,

Intrinsic resistance.

\begin{abstract}
A B S T R A C T
Saprophytic Non-fermenting Gram negative bacilli have emerged as important healthcare associated pathogens. These organisms are ubiquitous in nature particularly in soil \& water even found in hospital environment.This case series contains several cases of nonfermenters that were reported from Burdwan Medical College \& Hospital within 15 days. The increasing multidrug resistance shown by these important pathogens leave us with fewer option to treat severe life threatening infections.
\end{abstract}

Copyright $@ 2017$ Subhra Saha et al. This is an open access article distributed under the Creative Commons Attribution License, which permits unrestricted use, distribution, and reproduction in any medium, provided the original work is properly cited.

\section{INTRODUCTION}

Non-fermenting Gram-negative bacilli (NFGNB) are taxonomically diverse group of aerobic,non-sporing bacilli or coccobacilli that are either unable to utilize sugar as a source of energy or degrade them via oxidative instead of fermentative pathway.[1] These occur as saprophytes in environment \& were considered to be commensals or contaminants.[2-3] Due to their frequent isolation from clinical specimens \& their association with the disease pathogenic potential of these organisms has been established beyond doubt. Injudicious \& empirical use of antibiotics has enabled non-fermenting Gram negative bacilli (NFGNB) emerge as important healthcare-associated pathogens. [4] These organisms are ubiquitous in nature particularly in soil \& water. In the hospital environment they may be isolated from instruments such as ventilator machine humidifiers, mattreses \& other equipments as well as from skin of health care workers.[5] The importance of identification of these non-fermenters lies in the fact that most of them show multidrug-resistance pattern \& inherent resistance to many antibiotics. [6] There are very few studies from India whereas the various NFGNB isolated from patient's sample have been identified \& their clinical significance assessed. These cases were reported in a tertiary care hospital in Burdwan \& subsequently identified as non-fermenters.

\section{Case series description}

Case 1

A 45 year old male patient was admitted to the orthopedics

*Corresponding author: Subhra Saha

Department of Microbiology Burdwan Medical College surgery department in Burdwan Medical College \& Hospital in May, 2017 for chronic ulcer on right knee.

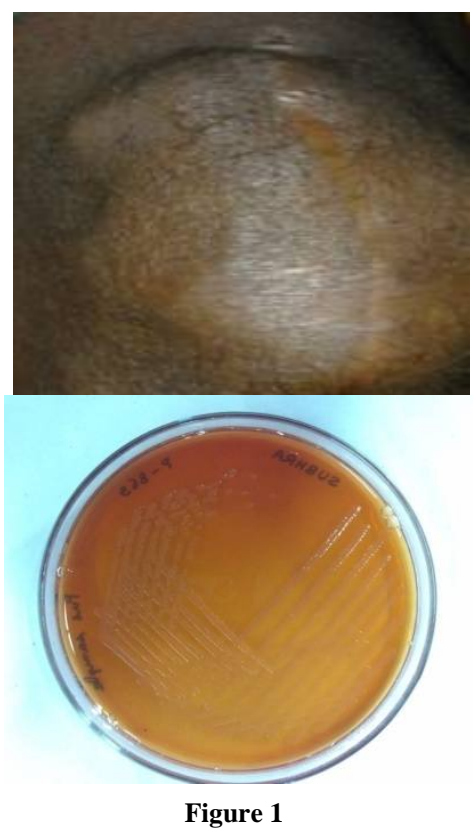

In conventional radiography \& ultrasonography there were no sign of osteomyelitis. The wound swab \& discharge was sent to microbiology department of Burdwan Medical college for bacterial culture \& sensitivity. Conventional culture \& Biochemical tests revealed that the causative organism was Gram negative coccobacilli that was catalase positive, oxidase negative, motile non-fermenter. Due to being inert in biochemical tests the isolate was identified as Bordetella trematum using Vitek-2 (Biomerieux) GN-ID card \& the 
sensitivity testing was done by conventional Kirby-Bauer disk diffusion method. In the result of sensitivity testing they showed resistance to first line of drugs such as cotrimoxazole, ceftazidime, amoxicillin \& ceftriaxone.

Case 2

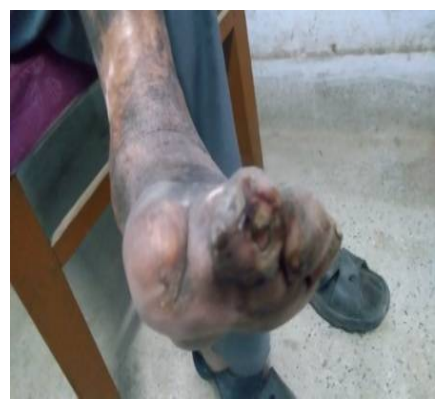

Figure 2

A 67 year old diabetic male patient presented to surgery OPD with chronic ulcer on second finger on left foot. First \& Second left foot fingers had been amputated 2 yrs ago due to diabetic foot syndrome. Wound swab was collected from the ulcer \& processed in Bacteriology laboratory of Burdwan Medical College. On processing Gram staining Gram negative coccobacilli was observed. As it is biochemically inert it was difficult to identify by conventional method. For this reason it was identified by Vitek-2 (Biomerieux) GN-ID card \& the organism was identified as Bordetella trematum. The sensitivity test was done by the Kirby-Bauer disk diffusion test. In the sensitivity test result it showed resistance to first line drugs ciprofloxacin, cotrimoxazole, ceftazidime and ceftriaxone.

Case 3

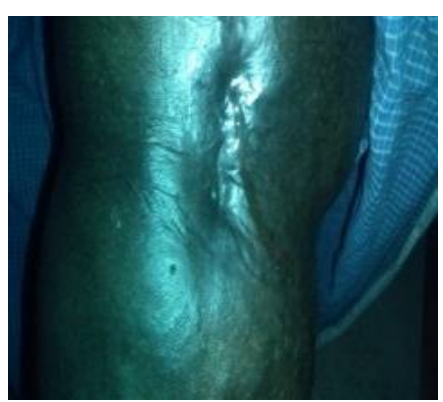

Figure 3

A 45 year old male patient came to dermatology OPD due to infection on the left leg from which there was a continuous foul smelling pus discharge from just above the knee for 25 yrs.After collection of the pus sample it was taken to bacteriology laboratory in Department of Microbiology of Burdwan Medical College. Based on biochemical characterization it was observed that the organism was Gram negative, rod shaped, aerobic, motile, oxidase positive, nonfermenter that was identified as Pseudomonas fluorescens. After using standard Kirby- Bauer disk diffusion technique \& by Vitek-2 AST card, it showed resistance to first line \& second line drugs such as amoxicillin, cotrimoxazole, ciprofloxacin, ceftriaxone and amikacin.

\section{Case 4}

A 27 year old male patient with open pyogenic infection having continuous foul smelling on right leg just below the knee for 4 years presented to dermatology OPD in Burdwan Medical College in May, 2017. Sample was collected \& further characterization was done in bacteriology laboratory in microbiology department of Burdwan Medical College. In the biochemical test the organism was identified as Gram negative coccobacilli Acinetobacter baumannii that is aerobic, oxidase negative, motile, non-fermenter. This was further confirmed by 16s rRNA gene sequencing carried out by ABI3500 Genetic analyzer. In the conventional Kirby-Bauer disk diffusion test it was found that this organism was resistant to first line drugs such as amoxicillin, cotrimoxazole, ceftazidime, ceftriaxone, ciprofloxacin \& second line drugs such as amikacin, imipenem $\&$ cefuroxime.

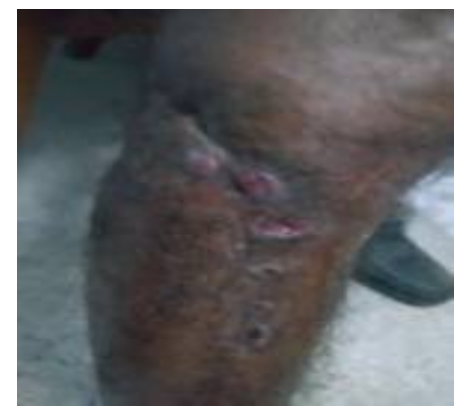

Figure 4

\section{DISCUSSION}

NFGNB that were considered to be contaminants in the past have now emerged as important healthcare-associated pathogens that are resistant to commonly used antibiotics.[9] For each of these organisms underlying host factors are strongly associated with outcome. Though earlier identification of non-fermenters based on biochemical tests was cumbersome now with availability of commercial systems like Vitek-2 (Biomerieux) GN-ID card the identification has become easier.[19] The interplay between the multidrug resistant pathogens \& increasing number of immune compromised patients poses a challenge for microbiologists \& clinicians likewise. Early diagnosis \& institution of empirical therapy based on local antibiogram data of institute would reduce mortality \& improve patient management.The intrinsic resistance to some antibiotics commonly used to treat infections makes the isolation of Bordetella trematum significant.[16-17]

\section{CONCLUSION}

Here we presented a case series of non-fermenters that were reported within 15 days from Burdwan Medical College \& Hospital. As non-fermenters are emerging pathogens showing multidrug resistance now-a-days so this case series has a great importance. Among these non-fermenters Bordetella trematum is extremely rare reported case that are intrinsically resistant to many antibiotics.

\section{Acknowledgement}

We the authors would like to thanks the hospital staffs, laboratory members for collection of samples \& further characterization of isolates.

\section{References}

1. Koneman EW, Allen SD, Janda WM, Schreckenberger PC, Winn WC. Introduction to Microbiology. In: Colour Atlas and Textbook of Diagnostic Microbiology, $6^{\text {th }}$ edition, Lippincott; Philadelphia : 1997; 171-566. 
2. Steinberg JP, Rio DC. Gram negative and Gram variable bacilli. In: Mandell GL, Bennett JE, Dolin R, editors. Principles and Practice of Infectious diseases. 6th ed. Vol. 2. Philadelphia, USA: Elsevier Publication; 2005. pp. 2751-68.

3. Gales AC, Jones RN, Forward KR, Linares J, Sader HS, Verhoef J. Emerging importance of multidrugresistant Acinetobacter species and Stenotrophomonas maltophilia as pathogens in seriously ill patients: Geographic patterns, Epidemiological features, and trends in the SENTRY antimicrobial surveillance program (1997-1999) Clin Infect Dis. 2001; 32:104-13.

4. McGowan JE., Jr Resistance in nonfermenting gramnegative bacteria: Multidrug resistance to the maximum. Am J Med. 2006; 119(6 Suppl 1):S29-36.

5. Mellmann A, Bimet F, Bizet C, Borovskaya AD, Drake $\mathrm{RR}$, Eigner U, et al. High interlaboratory reproducibility of matrix-assisted laser desorption ionization-time of flight mass spectrometry-based species identification of nonfermenting bacteria. J Clin Microbiol. 2009; 47:3732-4.

6. Fass RJ, Barnishan J, Solomon MC, Ayers LW. In vitro activities of quinolones, beta-lactams, tobramycin, and trimethoprim-sulfamethoxazole against nonfermentative gram-negative bacilli. Antimicrob Agents Chemother. 1996; 40:1412-8.

7. Rubin SJ, Granato PA, Wasilauskas BL. Glucose nonfermenting Gram negative bacteria. In: Lennette EH, Balows A, Hausler WJ Jr, Shadomy HJ, editors. Manual of Clinical Microbiology. 4th ed. Washington, D.C: American Society for Microbiology; 1985. pp. 330-49.

8. Quinn JP. Clinical problems posed by multiresistant nonfermenting gram negative pathogens. Clin Infect Dis. 1998; 27:S117-24.
9. Troillet N, Samore MH, Carmeli Y. ImipenemResistant Pseudomonas aeruginosa: Risk factors and Antibiotic susceptibility patterns. Clin Infect Dis. 1997; 25:1094-8.

10. Yashodara P, Shyamala S. Identification and characterization of nonfermenters from clinical specimens. Indian J Med Microbiol. 1997; 15:195-7.

11. Mishra B, Bhujwala RA, Shriniwas Nonfermenters in human infections. Indian J Med Res. 1986; 83:561-6.

12. Taneja N, Maharwal S, Sharma M. Imipenem resistance in nonfermenters causing nosocomial urinary tract infections. Indian J Med Sci. 2003; 57:294-9.

13. Rennie, R.P., Jones, R.N., Mutnick, A.H. Occurrence and antimicrobial susceptibility patterns of pathogens isolated from skin and soft tissue infections (report from the SENTRY Antimicrobial Surveillance Program (United States and Canada, 2000)) . Diagn Microbiol Infect Dis. 2003; 45:287-293.

14. Vandamme P, Heyndrickx M, Vancanneyt M, Hoste B, De Vos P, Falsen E, et al. Bordetella trematum sp. nov., isolated from wounds and ear infections in humans, and reassessment of Alcaligenes denitrificans Ruger and Tan 1983. Int J Syst Bacteriol 1996; 46:84958.

15. Daxboek F, Goerzer E, Apfalter P, Nehr M, Krause R. Isolation of Bordetella trematum from a diabetic leg ulcer. Diabet Med 2004; 21:1247-8.

16. Hernández-Porto M, Cuervo M, Miguel-Gómez MA, Delgado T, Lecuona M. Diabetic leg ulcer colonized by Bordetella trematum. Rev Esp Quimioter 2013; 26:72-3.

17. Clinical and Laboratory Standards Institute (CLSI). Performance Standards for Antimicrobial Susceptibility Testing, $23^{\text {rd }}$ Informational Supplement. Vol. 27. CLSI Document M100-S23. Wayne, PA: Clinical and Laboratory Standards Institute; 2013.

18. Funke G, Funke-Kissling P. Evaluation of the new VITEK 2 card for identification of clinically relevant gram-negative rods. J Clin Microbiol. 2004; 42:406771.

\section{How to cite this article:}

Subhra Saha et al (2017) 'Non Fermenters are Emerging From Pyogenic Lesions: A Case Series From Burdwan Medical College', International Journal of Current Advanced Research, 06(08), pp. 5397-5399.

DOI: http://dx.doi.org/10.24327/ijcar.2017.5399.0716 